\title{
GREETINGS VARIETY TO SHOW POLITENESS IN GORONTALO LANGUAGE
}

\author{
Dewi Dama \\ Fakultas Sastra dan Budaya, Universitas Negeri Gorontalo \\ Jl. Jenderal Sudirman No. 6 Kota Gorontalo \\ Email: dewi.dama@ung.ac.id
}

\begin{abstract}
This research aims to present the forms of greetings in Gorontalo Language and the examples used in society. The study focused on the use of Gorontalo language and took place in Ayula Tilango Kecamatan Bulango Selatan. The data were obtained through observation and elicitation. The results indicated various greetings based on Based on the findings, in Bahasa Gorontalo, there are, namely: Name in the form of kinship relationship (family connection - Vertically), name in the form of horizontal relationship (intimacy, friendship and body shape), name has a collective identifying character of the clan / fam (surname), name with religious title, name contains a custom title or an honors degree (given for personal achievements, a hero or died important person, important status in local government), and name contains a noble title.
\end{abstract}

Keywords: Greetings, naming, titles, Gorontalo Language.

\section{INTRODUCTIONS}

Study on Sociolinguistics field is massive. One of the topic that the writer concern is in the sub-field of linguistics called pragmatics. According to Wardhaugh \& Fuller (2015), pragmatics looks at meanings of utterances in context, and it is often discussed in contrast with the sub-filed called semantics, which is the study of meaning as part of the language system. Semantics focuses on the meanings of signs, and the relationship between these meanings, and includes the study of meanings of chunks of text. However, when these utterances are interpreted with reference to the context, including the setting, speakers, background knowledge, and so on, this falls into the realm of pragmatics.

Pragmatics, so this argument goes, is perceived as being distinct from sociolinguistics, but there is some overlap, hence the inclusion of some topics in pragmatics in this textbook. In particular, we incorporate topics which involve how

BAHTERA : Jurnal Pendidikan Bahasa dan Sastra, Volume Juli 2018 
the identities and relationships of speakers influence their linguistic choices and how they are interpreted (ibid., p.248). Politeness, moreover, is a key topic in pragmatics for several decades, has matured into an institutionalized research area with a voluminous book and journal literature, including its own recently launched periodical, the Journal of Politeness Research (Kasper, 2011).

From the perspective of sociolinguistic approach, the use of language "language use "is a form of social interaction that occurs in concrete situations; this means that from a sociolinguistic approach the language is studied in context socio-cultural and situations of use (Suwito, 1985: 5). In regard with socio-cultural and situations in the use of language factors status, age, gender, intimacy, purpose, norms / rules of language, type speech. These factors also affect the usage language (Alwi, 1995).

The word greeting includes one aspect of a deep language its use is always concerned with socio-cultural factors and situations its use. Some sociolinguists like Brown and Gilman (1960), Brown and Ford (1964), Ervin-Tripp (1972), Kridalaksana (1984), Sadtono (1977).
Brown and Gilman (1960) found two factors affecting the salary in IndoEuropean languages (German, Italian, Spanish, France) is the power factor of 'power' and solidarity 'solidarity'. Factor family and non family are also the determinants of greeting election (Slobin, 1963).

Furthermore, variation in showing such politeness and indirectedness has attracted the writer to overview them in more specific discussion about naming and title. Blum-Kulka (1987), based on experimental research in which research participants rated the politeness of requests, argues that on-record, conventionally indirect requests are considered more polite. Conventionally indirect requests include such linguistic forms as 'want' statements, for example, 'I want you to move your car' or 'I would like you to clean the kitchen.' Mild hints such as 'We don't want any crowding' as a request to move your car were not seen as equally polite, nor were bald imperatives such as 'Move your car' (examples from Blum-Kulka 1987, 133). She suggests that conventionally indirect requests are interpreted as polite because they are mitigated, but also because they do not 
require the work to interpret them that offrecord requests require of the addressee. Félix-Brasdefer (2005) supports this perspective on indirectness and politeness in his research on university students in Mexico. His research, based on the forms of requests used in role-playing tasks, shows that students are more likely to use indirect requests with a professor. Martin says that there are at least four fundamental factors in the selection of the right words to show politeness, greeting terms for others, consideration of people outside the group, social position, age and gender. Therefore, naming and title is one of interesting topics favorably explored in much research. As Mateos et al. (2011) states as follow:

"Naming practices are far from random, instead reflecting social norms and cultural customs(Hanks, 2003). They exist in all human groups(Alford, 1988) and follow distinct geographical and ethno-cultural patterns, even in today's globalised world. Any personal naming system serves two primary functions: to differentiate individuals from each other, and, simultaneously, to assign them to categories within a social matrix (Alford, 1988). Names thus provide important information about social structure(Lieberson, 2000). As such, "naming systems both reflect and help to create the conceptions of personal identity that are perpetuated within any society' (Alford R, $1998,167)$. The outcome is that distinctive naming practices in cultural and ethnic groups are persistent often even long after immigration to different social contexts(Tucker, 2003). We exploit such regularities in this international investigation."

According to the Central Bureau of Statistics (BPS) Year 2010, the number of ethnic groups in Indonesia amounted to 1,128 tribes. Such diversity is caused by differences in race of origin, geographic environment differences, differences in historical background, regional development, religious or belief differences, and adaptability or adjustability. Certain tribes have a surname that is passed from parent to child, some

BAHTERA : Jurnal Pendidikan Bahasa dan Sastra, Volume Juli 2018 
other tribes do not recognize the surname, for example Javanese culture which generally only have one name, that is name of giving or name of self. In connection with this, National Library of Indonesia from 2009 to 2011 has conducted a research and review of names in Indonesia. The investigation has been done in 24 (twenty four) provinces, and the results have been compiled in a form of List of family name, indigenous title and degree of nobility in Indonesia. In the year 2012, the list has been ready to use.

Kurniawati and Mulyani (2012) states, the compilation of the list of names is in regard with the library materials processing activities. Librarians often have difficulty recognizing the names of authors who have a clan / family name. They also sometime come across with problems to recall the title of nobility from various tribes and regions. That condition causes slow response on library processing routine. It is now very helpful as a reference in determining the title of the author of Indonesia who has the name of the clan, the title of 'adat' (local custom) and the title of nobility.

Gorontalo is the 32nd province in Indonesia, formerly Gorontalo is is one of the four ethnics located on North Sulawesi, namely: Bolaang Mongondow, Minahasa, Sangir Talaud, and Gorontalo. Along with the emergence of regional divisions with regard to regional autonomy, Gorontalo province was then established under Law No. 38 of 2000, and officialy being apart from Sulut on December 22, 2000. The total area of Gorontalo province is 11,090 $\mathrm{Km} 2$ and inhibited by 1.133 million people (Gorontalo Central Bureau of Statistics, 2010). The ethnic Gorontalo consists of ethnic Suwawa, Gorontalo, Limutu and Atinggolo. The ethnic Gorontalo people known from their relationship in the family, group-family/clan, traditional titles and noble titles. Gorontalo language is one of the languages used by people in the northern Sulawesi nearby Manado. This language spread from East to West of the province because the majority of Gorontalonese use the language in social interaction and daily transaction. In addition, as a custom language, it does exist in every beat of daily activities, such as: at a party, in a funeral, and in every custom performance.

However, it is argued that social development changed the existence of the language on its people, youg generation in

BAHTERA : Jurnal Pendidikan Bahasa dan Sastra, Volume Juli 2018 
particular. Either individuals or group of Gorontalonese has brought changes. The most notable change that decrease the use of the language is the advance of innovation in information and communication technology. Cultural alteration, as stated by Koentjaraningrat, is a consequence of cultural contacts, namely: Difusion, acculturation, and assimilation. It is our responsibility to preserve our culture. It can be done by preserving the language. The initial work done by the national library can be projected to local context, thus, In this article, the writer will present the research naming and title in Gorontalo language.

\section{METHODOLOGY}

The method used in this research is analytical descriptive method. The researcher zoomed in existing facts or phenomena that are empirically existing and still used by the public speakers. This descriptive method is used for obtaining the findings in this study. Data collection techniques used in this study is a technique refer intended to listen to the use of Gorontalo language by its speakers. This technique followed by basic techniques in the form of observation and set of survey by asking questions directly to the informants (Sudaryanto, 1993).

The data in this study is public speech in Gorontalo language. The data source is taken from the native speakers domiciled in Ayula Tilango Kecamatan Bulango Selatan. Data analysis is done through stages: (1) describing the data of naming and title; (2) classifying the forms of naming and title; (3) analyzing the forms of naming and title; and (4) making an inference to the forms of naming and title of Gorontalo language and its use in society.

\section{FINDINGS AND DISCUSSION}

\section{Name in the form of Vertical relationship}

In the kinship lineage, the language of Gorontalo is rich in hymns.

1) Bapu and Ne:ne, in Indonesian called grandparents. Ancient times also recognize greeting Teme and Tiley, which attached to the name of the first male nephew

2) Baba, Aba, Omu for Dad's call

3) Na:na and Mama for the greetings of the mother 
4) Omu, Patua, Patenga, Paade or Pasisa is a greeting to uncle

5) Tanthe, Matua, Matenga, Maade, Masisa is a greeting for aunt

6) Bantha (Puluwa), Uti, Nonu, Nunu are some calls for children / nephew / grandchildren

7) Nou, Mbui, Mo: Nu is some call for child / nephew / granddaughter

8) Wombu greetings for grandchildren and women

Name in the form of horizontal relationship

a. In a family relationship:

1) Eyi is a husband's husbandly greeting to his wife and vice versa

2) Kaka

3) Tata

4) Old, Satu, Dua, used in greeting husband or brother of husband / wife

5) Uwa, Sisa, Cii used in greeting wife or sister of husband / wife

b. In the second pronoun

The second Persona in Indonesian can be used as a communication greeter. Likewise, the language of Gorontalo. The second person in Gorontalo in free form
1) Timongoli and Yi'o to you. The first is a very polite second to greeting (equivalent)

2) Watiya or Wa'u to Me. The first is a very polite second to greeting (equivalent)

3) Timongoliyo greetings to them (very polite) Timongoli greetings to you

4) Amiyatiya greetings to us (very polite), Ami greetings to us (equivalent)

c. In a single third pronoun

The third Persona in Indonesian can be used as a greeter in communicating. Likewise, the language of Gorontalo. The third person in Gorontalo in free form

1) Tiyo greetings to him male or female d. In a posture relationship (nickname)

1) pahaya, mahaya greeting an old tall man

2) patinggi, matinggi greeting of parents who are tall

3) kapende, mapende greetings of shortbodied parents

4) pagode, magode, greetings elderly gentlemen

5) Palimbo, Balimbo, malimbo greeting parents who are short fat round 
6) Kapanja for tall person

7) Pakio - Makio for short dark people

8) Pakiki, makiki for short people

9) Pali mali average people

10) Kaputi, mamputi for older light color skinned person

11) Paita, maita for old people with dark skin

12) Kaita, Naita for young people with dark skin

Name has a collective identifying character of the clan / fam (surname)

Family names (Surname) that are hereditary/commonly exist in Gorontalo

1) Olii

2) Monoarfa

3) Biya

4) Laya

5) Niode

6) Hoeboelo atau Gobel

7) Kaluku

8) Boekoesoe

9) Dama

10) Pakaya

11) Wartabone

12) Lahay

13) Hadju

14) Ilahude

15) Lebie

16) Mohi
17) Laleno

18) Kadji

19) Tolinggi

20) Bobihoe

21) $\mathrm{KaU}$

22) Doda

23) Sunge

24) Katili

25) Biahimo

\section{Name with religious title}

In the old days this greeting always stuck with the title, but it is now barely used

1) Teme ... .. for the elderly man

2) Tiley ...... for the elderly women

3) Tuani .... For well-known religious teachers

4) Ti Kumisi to the commissioner

5) Guru .... For men whose profession is teaching

Name contains a custom title or an honors degree given for personal achievements

1) Ti Tulutani Lo Toyunuta devoted to Sri Sultan Hamengkubuwono X

2) Tapulu Lo Hunggia given to the former governor Gusnar Ismail

Name contains a custom title or an honors degree given for a hero or died important person

BAHTERA : Jurnal Pendidikan Bahasa dan Sastra, Volume Juli 2018 
1) Ta me ela lo madala (Omar Thariq Niode)

Name contains a custom title or an honors degree given for status in local government

1) Tauwa lo lipu is the name of Governor and mayor

2) Wuleya lo lipu for chief of district

3) Ta Uda'a for chief of villager

Name contains a noble title.

1) Ti Raja

2) Ti Putiri

\section{CONCLUSION}

Greetings variety to show politeness in Gorontalo language particularly in Ayula Tilango Kecamatan Bone Bolango is similar to Indonesian language or other languages as mentioned in previous theories.

Based on the findings, in Bahasa Gorontalo, there are, namely: Name in the form of Vertical relationship (family connection - Vertically), name in the form of horizontal relationship (intimacy,friendship and body shape), name has a collective identifying character of the clan / fam (surname), name with religious title, name contains a custom title or an honors degree (given for personal achievements, a hero or died important person, important status in local government), and name contains a noble title.

\section{REFERENCES}

Arbie, R. (2011). Hadrah dalam Multikultur Masyarakat Jaton di Minahasa Sulawesi Utara sebagai Pembentukan Karakter Bangsa. In: Kongres Internasional. Retrieved from Google Schoolar search engine

Arbie, R. and Mantau

M. (2012). Apresiasi Masyarakat terhadap Bahasa dan Sastra Jaton di Sulawesi Utara dan Gorontalo sebagai Wahana Pembentukan Karakter Makalah disajikan pada Seminar "Bulan Sastra dan Bahasa pp. 1-12. Retrieved from Google Schoolar search engine

Fasold, R. (1987). The sociolinguistics of society. New York: Basil Blackwell.

Fuller, R. W. (2015). An Introduction to Socioinguistics. UK: Wiley Blackwell Publishers Ltd. 
Harder, K. B. (1989). General/Theoretical Anthropology: Naming and Identity American Anthropologist; Oxford Vol. 91, Iss. 2, (Jun 1989): 473. Retrieved from Proquest database

Holmes, J. (2015). An introduction to sociolinguistics. London \& New York: Routledge.

Kasper, G. (2011). Locating Politeness in Interaction. Linguistik Indonesia. 1 - 17. Retrieved from Google Schoolar search engine

Kurniawati, R. D. \& Mulyani, S. (2012). Daftar Nama Marga/Fam, Gelar Adat dan Gelar Kebangsawanan Di Indonesia. Perpustakaan Nasional RI, Jakarta. ISBN 978-979-008-495-7. Retrieved from Google Schoolar search engine

Mashiri, P. (1999). Terms Of Address In Shona: A Sociolinguistic Approach. Zambezia, XXVI (1). Retrieved from Proquest database

Mateos, P., Longley, P. A. \& O'Sullivan, D. (2011). Ethnicity and Population Structure in Personal Naming Networks. PLoS One; San
Francisco Vol. 6, Iss. 9, Retrieved from Proquest database

Pateda, M. (2015). Sosiolinguistik. Bandung: CV. Angkasa.

Poruciuc, N. A. (2014). English and Romanian Personal Names as Identity Indicators in Medieval Documents. Mankind Quarterly; Washington Vol. 55, Iss. 1/2, 30-51.

Retrieved from Proquest database

Sambeka, F. (2017). Sistem Sapaan Nonkekerabatan Masyarakat Jepang Di Sulawesi Utara. Jurnal Kompetensi. Retrieved from Google Schoolar search engine Suparno, D. (2014). Sumbangsih bahasa uki dalam mengmbangkan leksikon Indonesia: tinjauan linguistic. Jurnal Dialektika. Vol.1, No. 2. Retrieved from Google Schoolar search engine

Tatuta, S. (2017). Sapaan Kekerabatan Dalam Bahasa Inggris Dan Bahasa Biak (Suatu Analisis Kontrastif). Jurnal Elektronik Fakultas Sastra Universitas Sam Ratulangi. Vol 1, No 3. Retrieved from Google Schoolar search engine 
BAHTERA: Jurnal Pendidikan Bahasa dan Sastra, Volume 17 Nomor 2 Juli 2018 http://journal.unj.ac.id/unj/index.php/bahtera/

P-ISSN : 0853-2710

E-ISSN : 2540-8968

\section{BAHTERA}

Traxler, M. J. (2012). Introduction to psycholinguistics: $\quad$ Understanding language science. Oxford: WileyBlackwell.

Wardhaugh, R., \& Fuller, J. M. (2015). An introduction to sociolinguistics.

Oxford: Wiley Blackwell 